
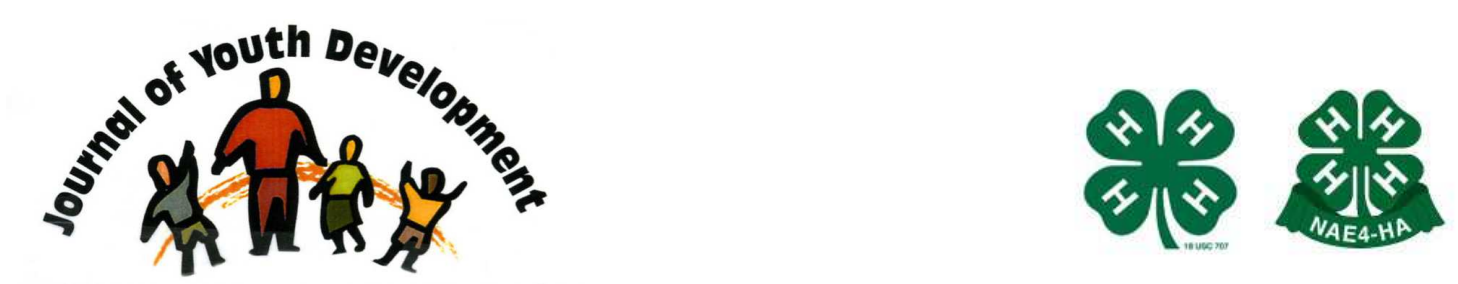

Bridging Research \& Practice

\title{
4-H "Survivor" Camp: \\ A Real-to-Life Experience in Living on Your Own
}

\author{
Carole Smith \\ 4-H Youth Development \\ Oregon State University Extension Service \\ La Grande, OR \\ carole.smith@oregonstate.edu \\ Janice Cowan \\ 4-H Youth Development \\ Oregon State University Extension Service \\ Baker City, OR \\ janice.cowan@oregonstate.edu \\ Debera Schreiber \\ 4-H Youth Development \\ Oregon State University Extension Service \\ Enterprise, OR \\ deb.schreiber@oregonstate.edu
}




\title{
JOURNAL OF YOUTH DEVELOPMENT \\ bridging research and practice

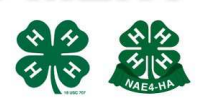

Volume 3, Number 2, Fall 2008

Article 080302PA002

\section{4-H "Survivor" Camp: A Real-to-Life Experience in Living on Your Own}

\author{
Carole Smith, Janice Cowan and Debera Schreiber \\ Oregon State University Extension Service
}

\begin{abstract}
In recent years many school district budgets have been reduced. Essential life skill classes, such as home economics and personal finance, have been eliminated leaving youth unprepared to live on their own. 4-H Survivor Camp was developed to meet this need. Survivor Camp provides the opportunity for youth to learn and practice basic life skills needed to make a successful transition from high school to young adulthood. The camp is based on seven core lessons: Living on a Budget, Renting an Apartment, Living with a Roommate, Food Preparation, Career Preparation, Self Awareness and Personal Reflection. Evaluation results show that youth who have participated in the program feel more prepared to face the realities of living on their own. The value of this curriculum is that it is adaptable for youth anywhere and in a variety of settings. This article discusses the real-tolife experiences taught at the camp and the related life skills reinforced.
\end{abstract}

\section{Introduction}

Something's missing from high school. Parents and teachers say it, and students do too. (The Oregonian, 2007). Chris, a student at Wilsonville High School in Portland, Oregon, responded to The Oregonian's survey question of what students wished they had learned in high school. "As a high school senior, I'm looking forward to going to college, but I've become painfully aware that I don't really have the necessary skills to survive out there in the world. I wish that somewhere among all those years of English, math, and science there were classes in home economics, (so I could learn how to cook), personal finance (so I could learn how to save money and pay my taxes), and automotive repair (so I could understand what's going wrong with my car)."

It's not just in Portland, Oregon that educators are aware of the lack of life skills necessary to ease the transition from high school to young adulthood. A survey from the Financial Literacy News, 2002, found that high school students lack financial knowledge and skills necessary to 
make wise financial decisions. Spencer (2003) states that even though youth may be employed and receive a salary, they lack the knowledge and ability to make the lifestyle choices necessary for successful money management. Teen years can be a training ground for responsible money management, but O'Neill (1992) describes these years as a time of "premature affluence" where spending is primarily on non-essentials and limited planning takes place.

A decade ago it was traditional for high school curricula to contain courses that provided youth with essential life skills needed to successfully live on their own. As pressure on schools has increased to test children and quantify learning, practical life skills are being dropped from the curriculum.

Some states are responding to this situation by creating or adapting materials for life skill education. Colorado State University specialists and 4-H Agents started a partnership with leading organizations in the state that shared a common goal to enhance the financial skills of youth (McKenna, 1999). Idaho 4-H Extension Educators adapted Illinois' "Welcome to the Real World" curriculum that explores career opportunities and finances (Spencer, 2003). The South Carolina Extension Service designed the "Money 2000" program for families; then wrote an adaptation for a youth audience called "Money My Way" (Porter, 1999). All of these programs address financial management and/or career planning goals. These types of activities will reinforce life skills such as decision-making, planning/organization, and wise use of resources.

Other life skills, just as important, can be incorporated into a curriculum or 4-H event to prepare youth for a successful transition to adulthood. The goal of youth programming is to provide developmentally appropriate opportunities for young people to experience life skills, to practice them, and apply them throughout their lifetime (Hendricks, 1998).

\section{Program Description}

4-H Survivor Camp was implemented to teach a number of life skills utilizing hands-on activities in a setting that allows each participant to immediately "practice" a newly introduced skill. This immediate reinforcement prepares youth for the transitional period from high school to adulthood. Youth attending the 3 day camp begin the weekend with designated roommates and a pre-assigned job, representative of the type of position they would qualify for with a high school education. Youth receive a paycheck for one month and prepare a budget reflecting anticipated expenses. As apartment groups, youth work together throughout the weekend to shop for an apartment utilizing classified ads, negotiate with landlords and utility companies, and pay routine bills as well as those unexpected expenses that occur. In addition, youth participate in activities that teach skills in balancing their checkbooks, searching and interviewing for jobs, planning and cooking nutritious meals (from scratch), and problem solving financial and social issues related to real life events.

\section{Need Identified}

Initially, the idea for a life skill camp of this caliber emerged from data collected at two focus groups conducted in Union County, Oregon. The county is located in the north eastern corner of Oregon, has a population of approximately 25,000 people and covers 2000 square miles. Principle industries are agriculture, timber, government education and manufacturing. The focus groups were held to formulate future programming needs for the county. Session participants were 4-H leaders, parents and older youth members. A key of concern issue identified in the process was the lack of basic life skill training being provided by local school districts or other youth organizations. With the reduction of education budgets, traditional 
classes in home economics, personal finance, and vocational classes were being eliminated in the school system. Attendees at the sessions appealed to the 4-H agent to help their children prepare to live on their own.

Through personal interviews with local school administrators and teachers throughout eastern Oregon, the need for life skill training was explored and validated as a real concern. To meet this concern the three 4-H agents from adjoining eastern Oregon counties wrote the curriculum, 4-H Survivor Camp.

\section{Target Audience}

Survivor camp is a 3-day camping event for $9^{\text {th }}-12^{\text {th }}$ grade youth. Youth are recruited by marketing the camp in 4-H newsletters and flyers distributed to teachers and counselors in high schools and alternative education facilities. Camp is open to all youth of target age throughout the state but enrollment is limited to 30 participants.

\section{Recruitment Tools}

The TV show "Survivor" provided a theme name and added a touch of excitement that proves successful in enticing youth to attend camp. The show also provided the model for the development of the program to help youth develop skills in dealing with real-life situations. 4-H Survivor Camp is scheduled in the winter months as a marketing tool and to add an element of adventure. An isolated camp location was selected, i.e., cell phones didn't work there, etc., to build on the "survivor" theme of living on one's own.

\section{Educational Goals}

The educational goals of Survivor Camp are structured to provide "practice" opportunities that resemble real-to-life experiences. The seven core lessons of the Survivor Camp curriculum are based on these educational goals. Below is a list of those experiences and the related life skill they teach:

- Living on a Budget. Creating budgets based on pre-assigned jobs, and then balancing a paycheck with "unexpected" bills. [decision-making, planning, organization, wise use of resources, keeping records]

- Renting an Apartment. Finding apartments in newspapers, reading/signing lease agreements, and negotiating with landlords. [teamwork, cooperation, negotiating]

- Living with a Roommate. [conflict management, sharing, communication]

- Food Preparation. Cooking nutritious meals from scratch. [lifestyle choices, goal setting, self-responsibility, financial management]

- Career Preparation. Interviewing with a potential employer for a job and preparing an effective resume. [social skills, self-esteem, communication)]

- Self Awareness. Become aware of personal strengths and values. [critical thinking, appreciation for others, empathy, caring]

- Personal Reflection. Reflecting on the day's activities through an evening "Tribal Council." [caring, empathy, learning to learn, accepting differences, problem-solving, critical thinking]

Utilizing a resident camping model provides the opportunity for youth to live in apartment groups with roommates and experience the stresses of living with non-family members. All Survivor Camp activities take place at the facility which encourages youth to focus on the challenge of "surviving" the weekend with the tools provided. Local businessmen are brought 
in to teach job search sessions and conduct mock interviews. 4-H Alumni are used as panel members for a roommate discussion session. Alumni share their personal experiences in living with roommates and how they worked through issues.

Team-building activities, instead of competitive ones, are interspersed throughout camp to create bonding, trust and cooperation among the participants. "Tribal Councils" an end-of-theday reflection time around a campfire, are used as an additional evaluation tool. Each youth expresses their feelings about the day and how they solved situations, whether it was roommate issues or financial "disaster bills."

\section{Program Evaluation}

One hundred twenty-eight participants in five different sessions completed an Institutional Review Board (IRB) approved pre and post test survey. Results were analyzed utilizing SPSS. A rating scale of 1-5 was utilized to determine the effectiveness of the real-life activities for introducing participants to the realities of living on their own. A score of 1 means "not true at all," a score of 5 means "extremely true." Before and after ratings were analyzed using a paired $t$ test. The analysis revealed a significant, positive change for each item $(p<.01)$. In particular, living in an apartment setting, using a camp setting, and participating in mock interviews provided the most real-life simulations for learning (Table 1).

Table 1

Participants' Rating of the Effectiveness of the Survivor Camp Model

\begin{tabular}{|c|c|c|c|c|c|}
\hline & $\mathbf{N}$ & Min & Max & Mean & $\begin{array}{c}\text { Std } \\
\text { Deviation }\end{array}$ \\
\hline $\begin{array}{l}\text { Living in an apartment setting with non-family members gave me } \\
\text { skills for negotiating \& compromising with roommates }\end{array}$ & 128 & 1 & 5 & 4.35 & .7763 \\
\hline $\begin{array}{l}\text { Reflection during the tribal council was a good way for me to } \\
\text { understand what I was learning at Survivor Camp }\end{array}$ & 128 & 1 & 5 & 4.09 & .9539 \\
\hline $\begin{array}{l}\text { Using a camp setting to teach life skills is more effective than a } \\
\text { classroom setting }\end{array}$ & 128 & 1 & 5 & 4.62 & .5868 \\
\hline $\begin{array}{l}\text { Paying my bills and creating my own budget helped me to } \\
\text { understand how to allocate limited financial resources }\end{array}$ & 128 & 1 & 5 & 3.95 & .8527 \\
\hline $\begin{array}{l}\text { Participating in a mock interview prepared me for a real job } \\
\text { interview }\end{array}$ & 128 & 1 & 5 & 4.35 & .8845 \\
\hline $\begin{array}{l}\text { Learning about different personality traits has helped me to be } \\
\text { more understanding of others }\end{array}$ & 128 & 1 & 5 & 4.34 & .8898 \\
\hline $\begin{array}{l}\text { I feel comfortable searching newspaper ads to find and rent } \\
\text { apartments }\end{array}$ & 128 & 1 & 5 & 4.06 & .8539 \\
\hline $\begin{array}{l}\text { Planning and cooking meals for myself and others taught me } \\
\text { how to share and delegate job tasks }\end{array}$ & 128 & 1 & 5 & 4.27 & .8334 \\
\hline
\end{tabular}

Comments from youth who participated include:

- I thought the landlord was responsible for turning on the electricity.

- I thought I was ready to leave home but after attending camp, I realized there are a lot of things I need to know.

- I didn't realize it would be so hard to budget my paycheck.

- I didn't realize it cost my parents so much money. 
- After listening to Jake \& Teresa (4-H alumni panel) I don't think I want to live with my friends, I think I'll stay at home when I go to college.

- I'm so glad they had this camp. I want to come back again next year.

One youth was surprised by the realization that all people aren't raised with the same values. His comments were "but why would a roommate say they would pay their share of expenses and then not do it."

Feedback collected through informal interviews with parents indicated their appreciation for the educational opportunity. The parents observed a change in their children's values towards money, their knowledge of the cost of providing for a household, the need to get a college education, and social diversity among their peers. Youth realize it is important to put careful thought into who they live with as a roommate. Participants often said they will think twice of living with their friends and will be sure to discuss how expenses will be divided.

\section{Conclusion and Application}

4-H Survivor Camp is positively impacting high school youth as they prepare to move into the next phase of their life. This program is designed to empower youth with life skills such as financial management, organization, and wise use of resources. 4-H Survivor Camp utilizes the 4-H experiential model where youth are encouraged to "plan, do and reflect" on situations that occur in everyday adult life.

Curriculum materials consist of seven core lessons that are strategically taught in a camp setting to provide youth with an experience of living on their own. The camp setting adds to the fun of the program but individual lessons can be taught independently in classroom settings. Survivor Camp curriculum has been shared with five other 4-H programs located throughout the United States as well as other youth organizations. Copies of the curriculum may be obtained by contacting the authors via email addresses.

This curriculum is applicable for alternative education, home school programs and other youth organizations. Each lesson can be used independently in a classroom setting to meet the objectives of the instructor.

\section{References}

Financial Literacy News. (2002). Survey says: Personal finance savvy of high school students is on decline. Spring, 2002, Volume 4, Issue 2.

Hendricks, P.A. (1998). Targeting Life Skills. (4-H0137A). Ames, IA: Iowa State University.

McKenna, J., \& Carroll, J. (1999). Collaborative Problem Solving: Financial Education for Youth. Journal of Extension [on-line] 37(5). Available at: http://www.joe.org/joe/1999october/a3.html

Nielsen, S. (reporter). "High School of their Dreams." The Oregonian. (1, April, 2007). E5.

O'Neill, B. (1992). Youth, money, and financial planning. Journal of Home Economics. Fall, 1216. 
Porter, N., \& Christenbury, J. (1999). Money 2000: A Model Extension Program. Journal of Extension [on-line] 37(1). Available at: http://www.joe.org/joe/1999february/a5.html

Spencer, M., Petty, B., Stimpson, J., Dees, L., \& Riley, L. (2003). "Welcome to the Real World" Positively Affects Youth Financial Management Skills, Knowledge, and Attitudes. Journal of Extension [on-line], 41(2) Available at: http://www.joe.org/joe/2003april/tt3.shtml

(C) Copyright of Journal of Youth Development Bridging Research and Practice. Content may not be copied or emailed to multiple sites or posted to a listserv without copyright holder's express written permission. Contact Editor at: patricia.dawson@oregonstate.edu for details. However, users may print, download or email articles for individual use. ISSN 2325-4009 (Print); ISSN 2325-4017 (Online) 